\title{
IMPLEMENTASI PEMBELAJARAN MULTIKULTURALISME BERBASIS ALAT PERAGA EDUKATIF SEBAGAI UPAYA MENGURANGI AKSI BULLIYING ANTAR PELAJAR
}

\author{
Dwi Gusti Ayu, Efa Aufa Azqia, Kokom Komariah, Shelvy Delia Sari. \\ dwigustiayu@gmail.com \\ Mahasiswa Fakultas Agama Islam
}

\begin{abstract}
ABSTRAK
Pembelajaran di sekolah dasar lebih banyak berorientasi kepada peningkatan aspek kognitif kurang memprioritaskan aspek sosial, khususnya berkaitan dengan multikulturalisme. Penelitian yang akan dilaksanakan ini ditujukan untuk menemukan efektivitas media pembelajaran multikulturalisme berbasis Alat Peraga Edukatif (APE) sejak usia pendidikan dasar yang merupakan salah satu upaya meningkatkan rasa persatuan dan kebhinekaan dan saling menghormati serta mewujudkan tujuan pendidikan nasional.Hal ini dilatarbelakangi semakin meningkatkan kasus bullying (kekerasan antar siswa) yang terjadi di sekolah baik bullying melalui verbal maupun non verbal. Metode penelitian ini adalah kualitatif deskriptif, agar tergambar secara utuh bagaimana proses pelaksanaan pembelajaran multikulturalisme melalui APE di Sekolah Dasar (SD). Luaran penelitian ini adalah terciptanya APE yang inovatif, tertanamnya sikap saling menghormati keanekaragaman, dan publikasi ilmiah berupa artikel.
\end{abstract}

Kata Kunci: Multikulturalisme, Bullying, Alat Perga Edukatif.

\section{PENDAHULUAN}

\section{Latar Belakang}

Indonesia memiliki berbagai macam budaya dari sabang sampai merauke di setiap daerah yang berada di Indonesia memiliki minimal satu kebudayaan yang mereka miliki. Pada era globalisasi ini banyak orang Indonesia yang tidak mengetahui kebudayaan yang terdapat di Indonesia terutama pada system pendidikan saat ini kebudayaan di Indonesia tidak terlalu di singgung pada proses belajar mengajar dan pada setiap daerah pun hanya memberitahu kebudayaan yang ada di daerah tersebut, seharusnya setiap proses belajar mengajar pada saat di sekolah guru memberitahu tentang kebudayaan yang ada di luar daerah tersebut. Agar setiap siswa mengetahui bahwa Indonesia itu multikuturalisme, terdapat berbagai kebudayaan, suku, agama, bahasa, adat, warna kulit, ragam daerah dan latar belakang lainnya.

Berkaitan dengan itu dari permasalahan yang ditemukan di berbagai sekolah saat ini adalah minimnya rasa saling menghormati antar siswa yang tercermin dari kurang menghargai keanekaragaman dan sering terjadinya kasus bullying. Menurut KPAI, saat ini kasus bullying menduduki peringkat teratas pengaduan masyarakat. Dari 2011 hingga agustus 2016, KPAI mencatat 692 korban kekerasan di sekolah (bullying) dan 442 pelaku kasus bullying di sekolah. pengaduan terkait masalah tersebut. Jumlah itu sekitar $50 \%$ dari total pengaduan di bidang pendidikan sebanyak 2490 kasus. Bullying yang disebut KPAI sebagai bentuk kekerasan di sekolah, mengalahkan tawuran pelajar, diskriminasi pendidikan, ataupun aduan pungutan liar. 
Untuk itu sangat diperlukan perhatian bagi seluruh masyarakat mulai dari keluarga, sekolah dan pemangku kebijakan untuk lebih peduli dalam menangani kasus ini. Karena bullying bukan hanya verbal yaitu dari ucapan atau kata-kata tapi juga non verbal yang menyangkut kekerasan fisik. Hal ini akan merusak perkembangan anak bangsa.

Melalui inovasi media pembelajaran melalui Alat Peraga Edukatif (APE) berbasis multikultularisme sebagai upaya menyadarkan siswa bahwa anak Indonesia harus bersatu, tidak boleh saling menyakiti karena perbedaan itu adalah anugrah teridah. Diharapkan melalui APE ini dapat meminimalisir terjadinya kasus bullying di sekolah.Siswa dapat mengetahui informasi tentang keanekaragaman Indonesia yang multikulturalisme.

Alat peraga edukasi multikulturalisme merupakan alat yang digunakan untuk proses penyampaian informasi pada saat terjadinya pembelajaran, alat yang digunakan ini berbasis multikulturarisme yang berarti setiap media pembelajaran harus dapat digunakan oleh berbagai kebudayanan dan dapat menghargai kebudayaan yang terdapat dipenjuru Indonesia.Media yang akan dirancang pada penelitian ini adalah media serbaneka yang berbentuk: movie maker, power point show, Banner/famlet dan games multikulturalisme. Sehingga diharapkan dapat mewujudkan proses pembelajaran lebih menarik dan menyenangkan yang bisa dikaitkan dengan berbagai mata pelajaran di Sekolah dasar.

\section{Alat Peraga Edukasi}

Menurut jurnal syamsuardi alat permainan edukatif adalah alat yang sengaja dirancang secara khusus untuk meningkatkan aspek - aspek perkembangan anak bahwa alat permainan edukatif adalah permainan yang dirancang khusus sebagai alat untuk bantu belajar dan dapat memoptimalkan perkembangan anak disesuaikan dengan usia dan tingkat perkembangannya.
Media adalah komponen sumber belajar atau wahana fisik yang mengandung materi instruksional di lingkungan siswa yang dapat merangsang siswa untuk belajar ( Azhar,2011: 2). Media pembelajaran merupakan sarana untuk memvisualisasikan proses belajar yang sering juga dipakai dalam pengajaran. Maka dari itu dalam proses pendidikan media sangat membantu guru untuk memudahkan dalam penyampaian pembelajaran dan menarik perhatian siswa untuk semangat dan antusias mengikuti kegiatan pembelajaran. Salah satu upaya yang dapat dilakukan oleh guru adalah melakukan inovasi pembelajaran. Berkaitan dengan itu pembelajaran multikulturalisme menjadi hal yang menarik perhatian untuk dikembangkan di sekolah dasar, guru dapat memanfaatkan beragam media sebagai alat menyampaikan informasi kepada siswa sehingga dapat meningkatkan rasa cinta tanah air.

\section{Multikulturalisme}

Hasil penelitian dari (Primawati:2012) pendidikan multikultural sebagai paradigma baru yang lahir pada akhir abad XX memiliki visi dan program mempersiapkan generasi muda menghadapi masyarakat dunia global dalam bingkai multikultural. Pendidikan multikultural sebagai program dirancang dengan berpedoman pada dimensi: content integration, knowledge construction, prejudice ruduction, equitable pedagogy, dan empowering school culture and social structure. Melalui rancangan ini, pendidikan multikultural diimplementasikan ke dalam pembelajaran multikultural berbasis nilai kebangsaan untuk menghasilkan subyek belajar yang memiliki kompetensi: (1) berwawasan dan berpengetahuan luas tentang konsep multikulturalisme (knowledge); (2) memiliki sikap arif dan bijak sebagai anggota masyarakat yang multikultur (disposition); dan (3) memiliki keterampilan dalam mengambil keputusan 
dan memberikan alternatif terhadap permasalahan multikultural dalam menjaga integrasi dan keharmonisan (skill).

\section{Bulliying}

Menurut psikolog Andrew Mellor, bullying adalah pengalaman yang terjadi ketika seseorang merasa teraniaya oleh tindakan orang lain dan ia takut apabila perilaku buruk tersebut akan terjadi lagi sedangkan korban merasa tidak berdaya untuk mencegahnya. Bullying tidak lepas dari adanya kesenjangan power/kekuatan antara korban dan pelaku serta diikuti pola repetisi (pengulangan perilaku). Lebih lanjut, Andrew Mellor menjelaskan bahwa ada beberapa jenis bullying, yakni: (1) bullying fisik, yaitu jenis bullying yang melibatkan kontak fisik antara pelaku dan korban. Perilaku yang termasuk, antara lain: memukul, menendang, meludahi, mendorong, mencekik, melukai menggunakan benda, memaksa korban melakukan aktivitas fisik tertentu, menjambak, merusak benda milik korban, dan lainlain. Bullying fisik adalah jenis yang paling tampak dan mudah untuk diidentifikasi dibandingkan bullying jenis lainnya; (2) bullying verbal melibatkan bahasa verbal yang bertujuan menyakiti hati seseorang. Perilaku yang termasuk, antara lain: mengejek, memberi nama julukan yang tidak pantas, memfitnah, pernyataan seksual yang melecehkan, meneror, dan lainlain. Kasus bullying verbal termasuk jenis bullying yang sering terjadi dalam keseharian namun seringkali tidak disadari; (3) bullying relasi sosial adalah jenis bullying bertujuan menolak dan memutus relasi sosial korban dengan orang lain, meliputi pelemahan harga diri korban secara sistematis melalui pengabaian, pengucilan atau penghindaran. Contoh bullying sosial antara lain: menyebarkan rumor, mempermalukan seseorang di depan umum, menghasut untuk menjauhi seseorang, menertawakan, menghancurkan reputasi seseorang, menggunakan bahasa tubuh yang merendahkan, mengakhiri hubungan tanpa alasan, dan lain-lain; (4) bullying elektronik merupakan merupakan bentuk perilaku bullying yang dilakukan melalui media elektronik seperti komputer, handphone, internet, website, chatting room, e-mail, SMS, dan lain-lain. Perilaku yang termasuk antara lain menggunakan tulisan, gambar dan video yang bertujuan untuk mengintimidasi, menakuti, dan menyakiti korban. Contoh cyber bullying yaitu bullying lewat internet.

Merujuk pada penjelasan Andrew Mellor tersebut, kasus kekerasan lingkungan pendidikan sebagaimana yang terjadi saat ini merupakan bentuk bullying fisik dan ini termasuk persoalan serius dan membahayakan, tidak hanya terhadap korban- tetapi juga pelaku dan saksi. Dampak bullying, sebagaimana menurut Victorian Departement of Education and Early Chilhood Development dapat terjadi pada: (1) pelaku, bullying yang terjadi pada tingkat SD dapat menjadi penyebab perilaku kekerasan pada jenjang pendidikanberikutnya; pelaku cenderung berperilaku agresif dan terlibat dalam gank serta aktivitas kenakalan lainnya; pelaku rentan terlibat dalam kasus kriminal saat menginjak usia remaja; (2) korban, memiliki masalah emosi, akademik, dan perilaku jangka panjang, cenderung memiliki harga diri yang rendah, lebih merasa tertekan, suka menyendiri, cemas, dan tidak aman, bullying menimbulkan berbagai masalah yang berhubungan dengan sekolah seperti tidak suka terhadap sekolah, membolos, dan drop out; (3) Saksi, mengalami perasaan yang tidak 
menyenangkan dan mengalami tekanan psikologis yang berat, merasa terancam dan ketakutan akan menjadi korban selanjutnya, dapat mengalami prestasi yang rendah di kelas karena perhatian masih terfokus pada bagaimana cara menghindari menjadi target bullying dari pada tugas akademik

Menurut seorang praktisi pendidikan, Prof Suyanto Ph.D- karakter adalah cara berpikir dan berperilaku yang menjadi ciri khas tiap individu untuk hidup dan bekerjasama, baik dalam lingkup keluarga, masyarakat, bangsa dan negara. Individu yang berkarakter baik adalah individu yang bisa membuat keputusan dan siap mempertanggung jawabkan tiap akibat dari keputusan yang ia buat. Sedangkan Pendidikan Karakter merupakan pendidikan nilai, pendidikan budi pekerti, pendidikan moral, pendidikan watak yang bertujuan mengembangkan kemampuan

\section{METODE PENELITIAN}

\section{Populasi dan Sampel}

Sumber data penelitian ini diperoleh dari hasi kegiatan wawancara, observasi, dan studi dokumentasi dari populasi SDN Leuwi Liang Bogor. Diacak secara terbatas sehingga digunakan dua sekolah yang terdiri dari kelas 5A dan 5B dengan jumlah 40 siswa. Narasumber penelitian ini yaitu, guru, siswa dan masyarakat di lingkungan sekitar.

\section{Waktu Penelitian}

Penelitian akan dilaksanakan selama 5 (lima) bulan, yang akan dimulai pada bulan Juni tahun 2018 sampai dengan November 2018. Tempat percobaan adalah di SDN Leuwi Liang Bogor. seluruh warga sekolah untuk memberikan keputusan baik-buruk, keteladanan, memelihara apa yang baik \& mewujudkan kebaikan itu dalam kehidupan sehari-hari dengan sepenuh hati. Pembentukan karakter merupakan salah satu tujuan pendidikan nasional. Pasal 1 Undangundang tentang Sistem Pendidikan Nasional (Sisdiknas) tahun 2003 menyatakan bahwa di antara tujuan pendidikan nasional adalah mengembangkan potensi peserta didik untuk memiliki kecerdasan, kepribadian dan akhlak mulia. Amanah UU Sisdiknas tahun 2003 itu bermaksud agar pendidikan tidak hanya membentuk insan Indonesia yang cerdas, namun juga berkepribadian atau berkarakter, sehingga nantinya akan lahir generasi bangsa yang tumbuh berkembang dengan karakter yang bernafas nilai-nilai luhur bangsa serta agama.

\section{Indikator capaian}

Penelitian kualitatif deskriptif ini dikatakan berhasil jika memenuhi ktriteria sebagai berikut:

1 Model media pembelajaran multikulturalisme berbasis Alat Peraga Edukatif (APE) bisa diterapkan di sekolah

2 Sikap saling menghormati, menyayangi, persatuan kesatuan dapat tercermin dalam kehidupan siswa

3 tidak ditemukannya lagi kasus bullying di sekolah

\section{Teknik Pengumpulan Data}

Data adalah bahan mentah yang perlu diolah sehingga menghasilkan informasi atau keterangan, yang menunjukkan fakta (Riduwan,2010). 
Teknik yang digunakan dalam mengumpulkan data penelitian ini adalah:

1 Wawancara

Wawancara adalah suatu cara pengumpulan data yang digunakan untuk memperoleh informasi langsung dari sumbernya. Ada beberapa faktor yang akan mempengaruhi arus informasi dalam wawancara, yaitu: pewawancara, responden, pedoman wawancara, dan situasi wawancara (Riduwan, 2010: 102).

\section{Observasi}

Observasi adalah pengamatan terhadap suatu objek yang diteliti baik secara langsung maupun tidak langsung untuk memperoleh data yang harus dikumpulkan dalam penelitian. Observasi kualitatif merupakan pengamatan langsung terhadap objek untuk untuk mengetahui keberadaan objek, situasi, konteks dan maknanya dalam upaya mengumpulkan data penelitian (Komariah, 2010: 105).

3 Studi Dokumentasi

Studi dokumentasi yaitu mengumpulkan dokumen data-data yang diperlukan dalam permasalahan penelitian lalu ditelaah secara intens sehingga dapat mendukung dan menambah kepercayaan dan pembuktian suatu kejadian (Komariah, 2010: 149).

\section{Tahapan dan Analisis data}

Metode pengumpulan dan analisis data penelitian kualitatif deskriptif bersifat interaktif, berlangsung dalam lingakaran yang tumpang tindih. Langkahlangkahnya disebut strategi pengumpulan dan analisis data, teknik yang digunakan fleksibel, tergantung pada strategi terdahulu yang digunakan dan data yang telah diperoleh (Sukmadinata, 2010:114). Milles dan Huberman (dalam Sangit, 2011) mengemukakan bahwa pendekatan dalam analisis data kualitatif terdiri dari reduksi data, display data, mengambil kesimpulan, dan verifikasi, yang dialakukan dalam bentuk interaktif dengan proses pengumpulan data sebagai suatu proses yang berlanjut, berulang, dan terus menerus hingga membentuk suatu siklus. Sebagaimana terlihat pada gambar 3.5.1 dibawah ini:

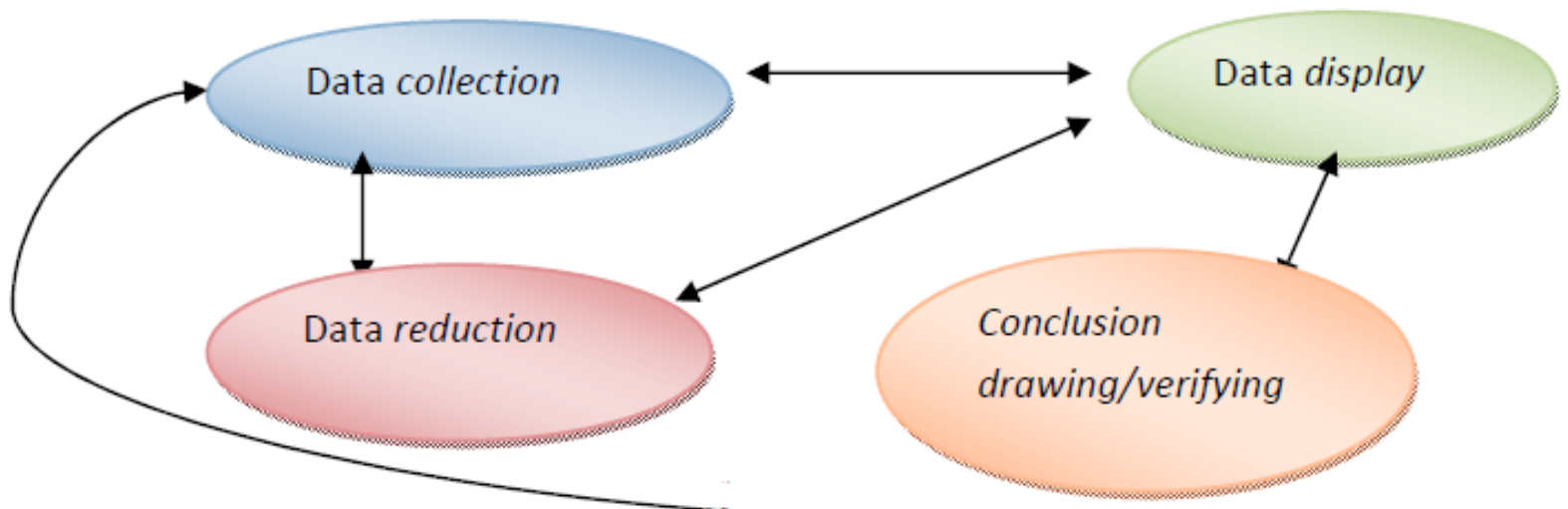

Analisis data kualitatif

Sumber: Miles and Huberman 
Dari gambar diatas dapat dijelaskan secara rinci sebagai berikut ini:

1 Koleksi data

Koleksi data adalah kegiatan ,engumpulkan berbagai data di lapangan sebagai hasil temuan.

2 Reduksi data

Mereduksi data dalam penelitian ini adalah sebagai proses merangkum data dari hasil observasi, wawancara, dan studi dokumentasi. Memilih, menyederhanakan, memilih hal-hal penting dan pokok yang dibutuhkan dalam kegiatan penelitian dilakukan secara terus menerus selama penelitian berlangsung sehingga peneliti mendapatkan data yang jelas.
3 Display data

Display data ini merupakan proses penyajian data, yaitu dilakukan setelah data terkumpul. Dengan disajikan maka peneliti akan mudah untuk membuat kesimpulan dan memahami data lebih jelas. Penyajian data dikumpulkan dari hasil wawancara, observasi dan studi dokumen dan akan mempermudah analisis data lebih lanjut.

4 Verifikasi data

Verifikasi adalah kegiatan menarik kesimpulan dari semua data-data yang diperoleh. Dari hasil reduksi dan display maka peneliti akan melakukan verifikasi menarik kesimpulan dari hasil penelitian yang telah dilakukannya

\section{BIAYA DAN JADWAL KEGIATAN}

Format Ringkasan Anggaran Biaya PKM-P

\begin{tabular}{|l|l|l|}
\hline No & Jenis Pengeluaran & Biaya (Rp) \\
\hline 1. & $\begin{array}{l}\text { Peralatan penunjang } \\
\text { Media pembelajaran, sewa printer serta kamera } \\
\text { SLR }\end{array}$ & Rp. 2000.000,- \\
\hline 2. & $\begin{array}{l}\text { Bahan habis pakai } \\
\text { Tinta print, kertas A4, fotocopy, ATK, dan internet }\end{array}$ & Rp. 2000.000,- \\
\hline 3 & $\begin{array}{l}\text { Perjalanan } \\
\text { Observasi sekolah dan lainnya ( selama 5 bulan ) } \\
\text { pelaksanaan penelitian }\end{array}$ & Rp. 3000.000,- \\
\hline 4 & Lain-lain: Administrasi,publikasi,seminar,laporan & Rp. $1550.000,-$ \\
\hline & Jumlah & Rp. $8.550 .000,-$ \\
\hline
\end{tabular}




\begin{tabular}{|l|l|l|l|l|l|l|}
\hline \multirow{2}{*}{ No } & \multirow{2}{*}{ Jenis Kegiatan } & \multicolumn{5}{|c|}{ Bulan } \\
\cline { 4 - 7 } & $\mathbf{1}$ & $\mathbf{2}$ & $\mathbf{3}$ & $\mathbf{4}$ & $\mathbf{5}$ \\
\hline 1. & Observasi & & & & & \\
\hline 2. & Studi Pendahuluan & & & & & \\
\hline 3. & $\begin{array}{l}\text { Pembuatan } \\
\text { instrument }\end{array}$ & & & & \\
\hline 4. & $\begin{array}{l}\text { Pembuatan perangkat } \\
\text { pembelajaran } \\
\text { (silabus,RPP,Media) }\end{array}$ & & & & & \\
\hline 5. & Uji coba media & & & & & \\
\hline 6. & $\begin{array}{l}\text { Pelaksanaan } \\
\text { penelitian }\end{array}$ & & & & & \\
\hline 7. & Laporan & & & & \\
\hline 8. & $\begin{array}{l}\text { Seminar (Publish } \\
\text { artikel/proceeding) }\end{array}$ & & & & & \\
\hline
\end{tabular}

\section{KESIMPULAN}

\section{Tujuan}

Tujuan khusus penelitian ini adalah berusaha untuk menemukan informasi yang

terkait dengan:

1 Profil pembelajaran multikulturalisme di Sekolah Dasar;

2 Proses pembelajaran multikulturalisme berbasis Alat Peraga

Edukatif (APE)

3 Efektivitaspenggunaan Alat Peraga Edukatif (APE) brbasis

multikulturalisme terhadap upaya meminimalisir kasus bullying di sekolah dasar

\section{Urgensi (Keutamaan Penelitian)}

Saat ini alat peraga edukasi yang digunakan di sekolah dasar lebih berorientasi kepada peningkatan aspek kognitif kurang memprioritaskan aspek sosial. Penelitian yang akan dilaksanakan ini ditujukan untuk menemukan efektivitas media pembelajaran multikulturalisme berbasis Alat Peraga Edukatif (APE)sejak usia pendidikan dasar yang merupakan salah satu upaya meningkatkan rasa persatuan dan kebhinekaan dan saling menghormati serta mewujudkan tujuan pendidikan nasional. Penelitian ini sangat penting didasarkan kepada pertimbangan sebagai berikut:

1 Meningkatnya kasus kekerasan anak di sekolah (bullying)

2 Pembelajaran multikulturalisme belum diajarkan denganmaksimal

3 Pembelajaran di SD cendrung membosankan bagi siswa dikarenakan minimnya keterampilan guru dalam membuat dan memanfaatkan Alat Peraga Edukatif (APE)

4 Masih minimnya inovasi dalam proses pembelajaran di SD

5 Pembelajaran di SD lebih sering fokus pada kecerdasan kognitif saja tanpa mengembangkan aspek sosial dan 
pengembangan karakter terutama rasa persatuan, saling menghormati dan kebhinekaan;

Temuan yang ditargetkan dan kontribusi terhadap ilmu pendidikan Temuan atau inovasi yang ditargetkan serta penerapannya dalam menunjang pembangunan dan pengembangan sosial humaniora atau Iptek-Sosbud:
1. Menghasilkan
bahan
ajar
pembelajaran
multikulturalisme
berupa Alat Peraga Edukatif (APE)

2. Mengimplementasi alat peraga edukasi serbaneka yang inovatif dan menarik

3. Mampu menciptakan pembelajaran yang penuh kenyamanan dan anti bullying

4. Sebagai upaya untuk meningkatkan kualitas pembelajaran dan sikap persatuan, saling menghormati yang lebih baik

\section{Luaran}

\begin{tabular}{|c|c|c|}
\hline No & Jenis Luaran & Keterangan (bentuk) \\
\hline 1 & $\begin{array}{c}\text { Bahan Ajar pembelajaran } \\
\text { multikulturalisme berbasis } \\
\text { APE }\end{array}$ & Alat Perag Edukatif (APE) \\
\hline 2 & $\begin{array}{c}\text { Alat Peraga Edukasi } \\
\text { Multikulturalisme }\end{array}$ & $\begin{array}{c}\text { Movie maker, PPT Show,Banner/Famlet dan } \\
\text { games }\end{array}$ \\
\hline 3 & Publikasi ilmiah & $\begin{array}{c}\text { Mengikuti Seminar nasional dan menjadi } \\
\text { pemakalah berupa artikel yang diterbitkan di } \\
\text { proceeding/jurnal terakreditasi }\end{array}$ \\
\hline
\end{tabular}

\section{Manfaat Penelitian}

Manfaat penelitian ini dapat diuraikan sebagai berikut:

Manfaat teoritis:

1 Menambah wawasan pengetahuan dan keterampilan bagi calon guru dan para guru di sekolah dasar berkaitan dengan pembelajaran multikulturalisme berbasis Alat Peraga Edukatif (APE);

2 Menjadi masukan bagi pengelola sekolah dan instansi pendidikan (Diknas atau Kemendikbud) sebagai inovasi media pembelajaran Manfaat praktis:

3 Media pembelajaran multikulturalisme berbasis Alat Peraga Edukatif (APE)yang dapat diimplementasikan di sekolah dasar;

4 Upaya inovasi pembelajaran untuk peningkatan kualitas proses dan hasil belajar dalam penanaman budaya cinta tanah airsejak pendidikan dasar;

5 Metode diseminasi media pembelajaran inovatif dan edukatif 


\section{REFERENSI}

Azhar, Arsyad.2011.Media Pembelajaran.

Di unduh dari Jakarta: Rajawali press. Primawati. 2012. pembelajaran multikultura http://www.kpai.go.id/berita/kpaimelalui pendidikan multikultura berbasis nilai kebangsaan, (online)

http://jurnal.unimed.ac.id/2012/index.php/j upiis/article/view/1117(diakses pada November 2017)

Davit Setyawan. 2014.KPAI : Kasus kasus-bullying-dan-pendidikankarakter

Syamsuardi. 2012. Penggunaan Alat Permainan Edukatif ( APE ) di taman kanank - kanak PAUD polewali kecamatan tanite riatang barat kabupaten bone. Vol 2 no 1. Jurnal Pendidikan.

Bullying dan Pendidikan Karakter. 